\title{
A Conceptual Research Model Proposal of Digital Marketing Adoption and Impact on Low Density Tourism Regions
}

\author{
Filipa Jorge $^{1,3}(\mathbb{D})$, Mário Sérgio Teixeira ${ }^{1,3}$ (D), \\ Ricardo Jorge Correia $^{2,3}$ (D), Ramiro Gonçalves ${ }^{1,4(\bowtie)}(\mathbb{D})$, \\ José Martins $^{1,4}\left(\mathbb{D}\right.$, and Maximino Bessa ${ }^{1,4}$ (D) \\ ${ }^{1}$ Universidade de Trás-os-Montes e Alto Douro (UTAD), Vila Real, Portugal \\ \{filipajorge, mariosergio, ramiro, jmartins, \\ maxbessa\}@utad.pt \\ 2 Instituto Poletécnico de Bragança (IPB), Bragança, Portugal \\ ricardoc@utad.pt \\ 3 Centro de Estudos Transdisciplinares para o Desenvolvimento (CETRAD), \\ Vila Real, Portugal \\ 4 INESC TEC, Porto, Portugal
}

\begin{abstract}
Nowadays, tourism faces the technology progress challenge. Tourists are changing the way they search for information and the way they buy tourism products and services. Therefore, becomes important to analyze the influence of relevant digital marketing tools on low density tourism regions success, measured through destination image, tourists' satisfaction and loyalty. The main aim of this article is to demonstrate the theoretical support of a model about the impact of digital marketing tools technologies on low density tourism region. To achieve this purpose, a literature review will be used as a methodological basis. This study also intends to contribute to the scientific debate through the improvement of knowledge in digital marketing tools applied to tourism and for this industry stakeholders.
\end{abstract}

Keywords: Digital marketing tools $\cdot$ Tourism $\cdot$ Low density regions

\section{Introduction}

World is more and more technological as time goes by, and technology has changed the ways that people live, work, and play [1]. In tourism field, this is also a reality [2]. The number of tourists who are booking travels, accommodation and other tourism products and services online is increasing and when they do not buy online, at least search for online information about destination [3]. For this reason, internet can be considered as a meeting point between tourists and tourism operators and it has influence on tourists' decision-making process.

Nowadays, internet becomes the place where consumers search for information, make their purchases, and give opinions about tourism products and services [4]. The internet is a level playing field for companies of all sizes, giving SMEs the chance to 
compete globally [5], and presents itself as a growing promotional channel for enterprises, that invest in digital marketing tools for their promotion and to improve the relation with customers [6]. These tools can effectively encourage tourists to share their experiences that will act as advertising messages and will help in the formation of a more positive target image. Digital marketing tools, such as digital commerce platforms or travel portals, allows a description of the tourism offer with information sharing in greater quantity [7].

Concerning to the tourism research context, tourists' satisfaction and loyalty is a goal for destinations and is also an indicator of successful destination management [8]. Furthermore, destination image is also very important due to the fact that it influences tourists' destination choice and future behaviours [9]. Emotional connection of the tourist with the destination is pointed as desirable and recommendable in the era of tourism of experiences [10].

Through a literature review of digital marketing tools on tourism field, this article proposes a conceptual model for further investigation. In this model we intend to evaluate digital marketing variables as determinants of tourism destination image and tourists' satisfaction and loyalty. This article is composed by five sections. The first section concerns to the introduction; the second section is the literature review, that focus on the review of scientific literature relevant to the subject under study; in the third section are presented the research model, the hypotheses proposed and their theoretical justification; in the fourth section it is exposed this work main contributions; and finally, in the fifth section are exposed the conclusions and explain this model future research.

\section{Literature Review}

Digital marketing strategies have a very high potential impact in the tourism sector [2]. In this sector, digital marketing strategies should seek to arouse in the consumer/tourist the desire to search more information about the tourism destination as well as the experiences that this destination can provide to them, with the main objective to inspire them to visit it [11].

The use of websites in tourism sector have a great importance, because tourists value the contents and information presented there [12]. Moreover, websites have impact on tourists' decision making [13] and destination image [14, 15]. With this in mind, tourism operators use websites to promote their products for their consumers, so they can access this information anywhere at any time [16].

Tourists are highly influenced by information that is available for them on internet, in particular, information expressed on comments or reviews made by consumers that are able to influence the tourist decision making process [17, 18]. These comments promote trust creation in tourists during the process of choosing a tourism destination, for the reason that tourists tend to trust on the reviews posted by their peers [19]. Because of this, online tourists' reviews, referenced in the literature as electronic Word Of Mouth (e-WOM) can be seen as important for tourism destinations image formation process.

Social media can also be extremely useful in the tourism sector, since they represent an information source about tourists, which will allow understand tourists' preferences and how respond to these preferences [20]. Therefore, social media play a vital role in 
tourists' decision-making [21]. The use of social networks by tourists changed the way how tourists research and find information, because these platforms provide the collaborative production of information about tourism destinations and organizations operating in this industry [22].

Social media are also the place where consumers post photos, videos and their opinions about tourism products and services. This type of content generated by tourists can be defined as e-WOM. The concept fusion between social media and e-WOM rises the concept of social media word of mouth, or just s-WOM [23, 24].

Email is present in consumers' daily life and they check inbox frequently [25]. This is a still very important digital marketing tool, because allows an active communication with customers, keeping in frequent contact with them [26-28]. Email allows the personalized communication to send information to potential consumers, reason because it is used as marketing tool [27].

Nowadays, almost every tourist has smartphone and use it to booking hotels, purchase airline tickets, to search information about the destination and other travel activities [29]. Moreover, mobile devices are able to improve transactions, but also to provide guides even when the tourist is in the destination [4]. So the use of smartphones and other mobile devices occur before and during the travel.

In the follow Table 1, it will be presented the most recent articles that focus their research in tourists' technology acceptance. These articles were retired from Web of Science data basis using as key-words technology acceptance and tourism.

Table 1. Articles focused on tourists' technology acceptance

\begin{tabular}{l|l|l|l}
\hline Authors (year) & DM tool & Models used & Tourism destination \\
\hline $\begin{array}{l}\text { Hur et al. } \\
\text { (2017) [30] }\end{array}$ & $\begin{array}{l}\text { Social } \\
\text { Media }\end{array}$ & $\begin{array}{l}\text { ELM } \\
\text { Uses and Gratifications } \\
\text { Theory (UGT) }\end{array}$ & Korea \\
\hline $\begin{array}{l}\text { French et al. } \\
\text { (2017) [31] }\end{array}$ & $\begin{array}{l}\text { Social } \\
\text { Media } \\
\text { Behavior } \\
\text { Social Capital } \\
\text { Self-determination } \\
\text { theory }\end{array}$ & Not mentioned \\
\hline $\begin{array}{l}\text { Fang e al. } \\
\text { (2017) [32] }\end{array}$ & $\begin{array}{l}\text { Mobile } \\
\text { Application }\end{array}$ & $\begin{array}{l}\text { Stimuli, Organism and } \\
\text { Response Model }\end{array}$ & Chengdu (City of China) \\
\hline $\begin{array}{l}\text { Fong et al. } \\
\text { (2017) [33] }\end{array}$ & $\begin{array}{l}\text { Mobile } \\
\text { Application }\end{array}$ & UTAUT & $\begin{array}{l}\text { Not mentioned (sample: } \\
\text { Chinese tourists) }\end{array}$ \\
\hline $\begin{array}{l}\text { Lin and Chen } \\
(2017) \text { [34] }\end{array}$ & Application & $\begin{array}{l}\text { TAM } \\
\text { UGT }\end{array}$ & Thailand \\
\hline $\begin{array}{l}\text { Herrero et al. } \\
(2017) \text { [35] }\end{array}$ & $\begin{array}{l}\text { Social } \\
\text { Media }\end{array}$ & UTAUT2 & Spanish destination \\
\hline $\begin{array}{l}\text { Balouchi et al. } \\
(2017) \text { [36] }\end{array}$ & e-WOM & TAM & $\begin{array}{l}\text { Not mentioned (sample: } \\
\text { Iranian tourists) }\end{array}$ \\
\hline $\begin{array}{l}\text { Koch and Tritscher } \\
(2017) \text { [37] }\end{array}$ & $\begin{array}{l}\text { Social } \\
\text { Media }\end{array}$ & TAM & Not mentioned \\
\hline
\end{tabular}




\section{Research Model and Hypotheses}

In this section will be exposed the conceptual model hypotheses proposed and presented in Fig. 1. Moreover, these hypotheses will be justified bellow based on relevant scientific literature.

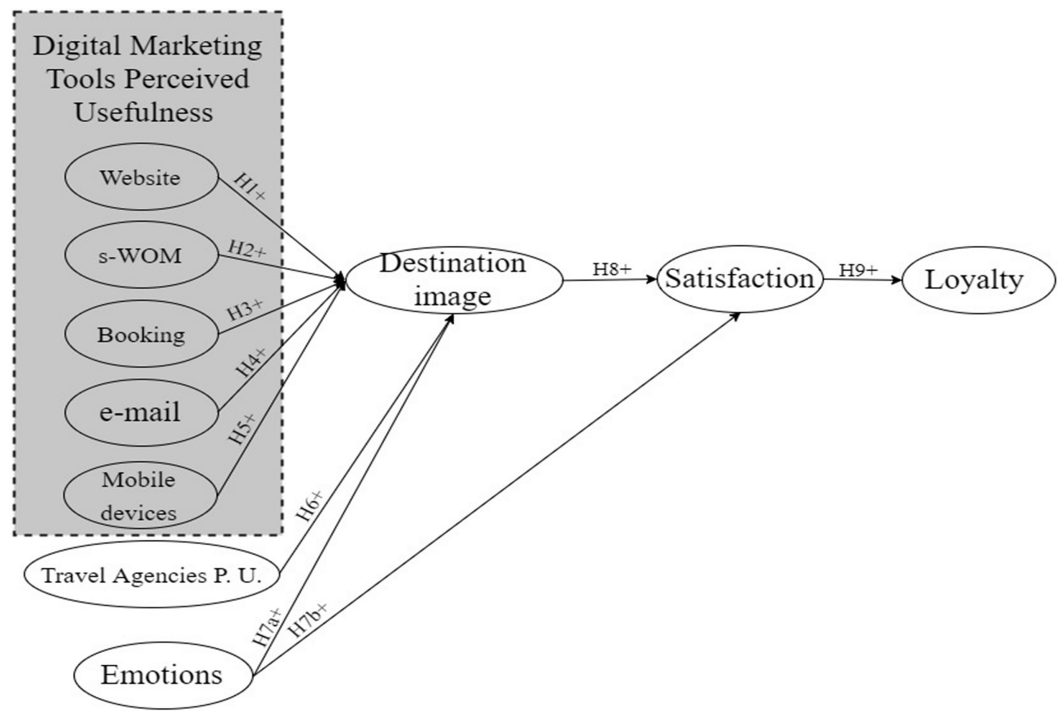

Fig. 1. Conceptual model proposed

Destination image is defined by [38] "as the sum of beliefs, ideas, and impressions that a person has of a destination". According to [39], destination image can be influenced by primary and secondary sources of information. In conformity to this information it is proposed that destination image can be influenced by tourists' perceived usefulness of digital marketing tools, such as website, e-mail, mobile devices, booking and, s-WOM.

Website quality has demonstrated that have influence on brand image [40]. For [41] website characteristics also demonstrated influence on non-profit organizations image. In tourism field, [15] used an experimental design to analyze the effect of website characteristics in destination image, verifying that website design has impact on destination image. [14] also verified, with an experimental design, that tourists' exposure to a website has impact on cognitive and overall destination image. Therefore, it is suggested the following hypothesis:

H1 - Website perceived usefulness has a positive and significant influence on Destination Image.

According with several studies, e-WOM has a positive influence on destination image [18, 42, 43]. Moreover, information quality in social media was positively related with destination image [44]. Knowing that both e-WOM and social media 
websites have influence on destination image, besides reviews that compose e-WOM are written mostly on social media websites. Therefore, it is proposed the use of the s-WOM as antecedent of destination image in the following hypothesis:

H2 - s-WOM perceived usefulness has a positive and significant influence on Destination Image.

Booking can be understood as the electronic commerce of tourism products and services. According to [45], Porto and North of Portugal region, where this low density region is implanted, $36.3 \%$ of total interviewed tourists book their tourism products through digital means. So, it is relevant to understand if booking platforms have information capable of influence tourists' perception of destination image as proposed in the following hypothesis:

H3 - Booking perceived usefulness has a positive and significant influence on Destination Image.

Email is a digital marketing tool that tourism operators use to build a relationship with tourists, to promote a destination, to send information about tourism products, and to guide tourists to websites. We didn't found any study that relate e-mail perceived usefulness and (destination) image. However, [27] proved that email marketing has a positive effect on loyalty, and suggested the further investigation of this relationship. In this model, we present this relationship with some mediator variables as destination image. So, it is proposed the following hypothesis:

H4 - e-mail perceived usefulness has a positive and significant influence on Destination Image.

[46] have suggested to study in future research the influence of mobile apps on destination image. More recently, [47] tested and verified the influence of mobile app perceived usefulness in destination image, mediated by online experience. With this in mind, it is suggested the following hypothesis:

H5 - Mobile devices perceived usefulness has a positive and significant influence on Destination Image.

As opposed to digital marketing tools it is introduced conventional means of making tourism products purchases, as by travel agencies. This inclusion is justified by [45] that analyses the tourists from Porto and North of Portugal, where this low density region is implanted, in which it is stated that $48,1 \%$ of leisure tourists buy their tourism products through digital means and $42,9 \%$ of them buy their trips in travel agencies. Concerning this information, it is important to understand if travel agencies have a similar role in the formation of destination image comparing with the digital marketing tools referenced above. Therefore, it is suggested the following hypothesis:

H6 - Travel agencies perceived usefulness has a positive and significant influence on Destination Image.

Emotions were already used as antecedents of brand image [48, 49], and, in a tourism context, emotions can influence the destination image [50]. If emotions generated from the tourism experience were positive, the perceptions about destination image, will also be positive. Therefore, we propose the following hypothesis.

$H 7 a-$ Emotions have a positive and significant influence on Destination Image.

Tourist satisfaction can be described as the emotional reaction to their tourism experiences [50, 51]. Several tourism studies have demonstrated the relationship between emotions and tourists' satisfaction [50, 52]. Positive emotions also are 
antecedents of satisfaction in tourism services as restaurants [53, 54], museums [55] and, theme parks [56], so we propose the following hypothesis:

$H 7 b-$ Emotions have a positive and significant influence on tourist Satisfaction.

Previous studies confirm a relationship significant and positive between Destination Image and tourist satisfaction (e.g. [52, 57]). According to this, it is proposed the following hypothesis:

H8 - Destination Image has a positive and significant influence on tourist Satisfaction.

Because it is more expensive to acquire new customers than to maintain existing ones, loyalty is very studied. In tourism context, destination experience is evaluated, and tourists' loyalty can be considered as the intention to revisit and recommend destination to friends and relatives [9]. Several studies confirm a significant and positive relationship between tourists' satisfaction and loyalty [8, 52, 57, 58]. Attending to the above discussion, it is suggested the following hypothesis:

H9 -Satisfaction has a positive and significant influence on tourist Loyalty.

\section{Contributions}

The most of studies focus in destinations as cities and countries (e.g. [59-61]). Otherwise, this research proposal is focused in a low density region which is recently promoted as a tourism destination. For low density regions, tourism can be presented as a path to development because it is able to bring people who will experience local traditions and knowledge, stimulating the local economy through increased consumption.

Furthermore, this is a new and innovative model that results from the joining of different knowledge areas of variables (new technologies acceptance, marketing, consumer behaviour and tourism destination management), bringing this aggregation an interdisciplinary approach to this proposal.

With this model, will be expected to understand the influence of digital marketing tools perceived usefulness on Douro tourists' behaviour, namely on Douro destination image and their tourists' satisfaction and loyalty. This empirical model results will be communicated to local tour operators and tourism industry stakeholders, allowing them to communicate with tourists more effectively using the digital marketing tools that will be proven as most relevant for those causal relationships.

According the literature, empirical studies using latent variables contain only one digital marketing tool in tourism context (e.g. $[12,19,25,62,63])$. The only study that uses three tools is not in the tourism field but about sports marketing [64]. So, in the tourism field remains an opportunity to explore the impact of several digital marketing tools which have not yet been studied together on destination image and tourists' satisfaction and loyalty. Furthermore, this article aims to contribute towards knowledge about Digital Marketing tools usefulness and valuation for tourism destinations and theses industry firms' strategies. 


\section{Conclusions and Future Research}

Information technologies are transforming the tourism industry [4]. Across the years, technologies empower tourists, because using them capacitates tourists to identify, customize and purchase tourism products, but technologies also help tourism industry in the globalization process [2]. Moreover, low-density tourism regions should use technology to improve their attractiveness.

Success of marketing destinations should be analyzed through the destination image, tourists' satisfaction and loyalty [57]. So, it is proposed to introduce several antecedents to this model of success, namely, digital marketing tools, travel agencies perceived usefulness and emotions.

The model presented above will be tested empirically during this year. Data collection for this research will be done using survey method through personnel interviews to tourists with the support of a questionnaire. Empirical data will be analyzed using quantitative methods, more specifically structural Equation Modelling. This technique is used to test the validity of theoretical models that define causal relationships between latent variables. The use of Structural Equation Modelling is in agreement with previous studies [18, 35, 47].

Acknowledgements. This text is part of UTAD's CETRAD R\&D project entitled DOUROTUR Tourism and technological innovation in Douro, operation NORTE-01-0145-FEDER-000014, co-financed by European Regional Development Fund (FEDER) through NORTE 2020 (Northern Regional Operational Program 2014/2020).

\section{References}

1. Chen, J., Teng, L., Yu, Y., Yu, X.: The effect of online information sources on purchase intentions between consumers with high and low susceptibility to informational in fluence. J. Bus. Res. 69, 467-475 (2016)

2. Buhalis, D., Law, R.: Progress in information technology and tourism management: 20 years on and 10 years after the Internet-The state of eTourism research. Tour. Manage. 29(4), 609623 (2008)

3. Castañeda, J.A., Frías, D.M., Rodríguez, M.A.: Antecedents of internet acceptance and use as an information source by tourists. Online Inf. Rev. 33(3), 548-567 (2009)

4. Ukpabi, D.C., Karjaluoto, H.: Consumers' acceptance of information and communications technology in tourism: a review. Telemat. Inform. 34(5), 618-644 (2017)

5. Manarte, N., Teixeira, M.S.: e-Marketing. In: Cruz-Cunha, M.M., Varajao, J. (eds.) Innovations in SMEs and Conducting e-Business: Technologies, Trends and Solutions, pp. 187-203. IGI Global, Hershey (2011)

6. Sousa, S., Teixeira, M.S., Gonçalves, R.: A aplicação do e-marketing em empresas de uma região ultraperiférica - região autónoma da madeira. RISTI Rev. Iber. Sist. e Tecnol. Inf. 7(1), 17-32 (2011)

7. Semerádová, T., Vávrová, J.N.: Using a systemic approach to assess Internet marketing communication within hospitality industry. Tour. Manage. Perspect. 20, 276-289 (2016)

8. Wu, C.W.: Destination loyalty modeling of the global tourism. J. Bus. Res. 69(6), 22132219 (2016) 
9. Zhang, H., Fu, X., Cai, L.A., Lu, L.: Destination image and tourist loyalty: a meta-analysis. Tour. Manage. 40, 213-223 (2014)

10. Martins, J., Gonçalves, R., Branco, F., Barbosa, L., Melo, M., Bessa, M.: A multisensory virtual experience model for thematic tourism: a port wine tourism application proposal. J. Destin. Mark. Manage. 6(2), 103-109 (2017)

11. Kah, J.A., Lee, C.K., Chung, N., Wiley, J.: Evaluating travel website motivational communication using a structural equation modelling approach. Int. J. Tour. Res. 12(6), 787-802 (2010)

12. Mandal, S., Roy, S., Raju, A.G.: Exploring the role of website attractiveness in travel and tourism: empirical evidence from the tourism industry in India. Tour. Plan. Dev. 14(1), 110 134 (2017)

13. Ladhari, R., Michaud, M.: eWOM effects on hotel booking intentions, attitudes, trust, and website perceptions. Int. J. Hosp. Manage. 46, 36-45 (2015)

14. Jeong, C., Holland, S., Jun, S.H., Gibson, H.: Enhancing destination image through travel website information. Int. J. Tour. Res. 14(1), 16-27 (2012)

15. Rodríguez-Molina, M.A., Frías-Jamilena, D.M., Castañeda-García, J.A.: The contribution of website design to the generation of tourist destination image: the moderating effect of involvement. Tour. Manage. 47, 303-317 (2015)

16. Sun, S., Ka, D., Fong, C., Law, R., He, S.: An updated comprehensive review of website evaluation studies in hospitality and tourism. Int. J. Contemp. Hosp. Manage. 29(1), 355373 (2017)

17. Filieri, R., Alguezaui, S., McLeay, F.: Why do travelers trust TripAdvisor? Antecedents of trust towards consumer-generated media and its influence on recommendation adoption and word of mouth. Tour. Manage. 51, 174-185 (2015)

18. Jalilvand, M.R., Samiei, N., Dini, B., Manzari, P.Y.: Examining the structural relationships of electronic word of mouth, destination image, tourist attitude toward destination and travel intention: an integrated approach. J. Destin. Mark. Manage. 1(1-2), 134-143 (2012)

19. Abubakar, A.M., Ilkan, M.: Impact of online WOM on destination trust and intention to travel: a medical tourism perspective. J. Destin. Mark. Manage. 5(3), 192-201 (2016)

20. Dellarocas, C.: The digitization of word of mouth: promise and challenges of online feedback mechanisms. Manage. Sci. 49(10), 1407-1424 (2003)

21. Leung, D., Law, R., van Hoof, H., Buhalis, D.: Social media in tourism and hospitality: a literature review. J. Travel Tour. Mark. 30(1-2), 3-22 (2013)

22. Zeng, B., Gerritsen, R.: What do we know about social media in tourism? A review. Tour. Manage. Perspect. 10, 27-36 (2014)

23. Balaji, M.S., Khong, K.W., Chong, A.Y.L.: Determinants of negative word-of-mouth communication using social networking sites. Inf. Manage. 53(4), 528-540 (2016)

24. Hajli, N., Lin, X., Featherman, M., Wang, Y.: Social word of mouth: how trust develops in the market. Int. J. Mark. Res. 56(5), 387-404 (2014)

25. Reimers, V., Chao, C.W., Gorman, S.: Permission email marketing and its influence on online shopping. Asia Pac. J. Mark. Logist. 28(2), 308-322 (2016)

26. Chaffey, D.: Applying organisational capability models to assess the maturity of digital-marketing governance. J. Mark. Manage. 26(3-4), 187-196 (2010)

27. Merisavo, M., Raulas, M.: The impact of e-mail marketing on brand loyalty. J. Prod. Brand Manage. 13(7), 498-505 (2004) 
28. Moustakas, E., Ranganathan, C., Duquenoy, P.: E-mail marketing at the crossroads: a stakeholder analysis of unsolicited commercial e-mail (spam). Internet Res. 16(1), 38-52 (2006)

29. No, E., Kim, J.K.: Determinants of the adoption for travel information on smartphone. Int. J. Tour. Res. 16(6), 534-545 (2014)

30. Hur, K., Kim, T.T., Karatepe, O.M., Lee, G.: An exploration of the factors influencing social media continuance usage and information sharing intentions among Korean travellers. Tour. Manage. 63, 170-178 (2017)

31. French, A.M., Luo, X.R., Bose, R.: Toward a holistic understanding of continued use of social networking tourism: a mixed-methods approach. Inf. Manage. 54, 802-813 (2017)

32. Fang, J., Zhao, Z., Wen, C., Wang, R.: Design and performance attributes driving mobile travel application engagement. Int. J. Inf. Manage. 37(4), 269-283 (2017)

33. Fong, L.H.N., Lam, L.W., Law, R.: How locus of control shapes intention to reuse mobile apps for making hotel reservations: Evidence from chinese consumers. Tour. Manage. 61, 331-342 (2017)

34. Lin, H.F., Chen, C.H.: Combining the technology acceptance model and uses and gratifications theory to examine the usage behavior of an augmented reality tour-sharing application. Symmetry 9(7), 113 (2017)

35. Herrero, Á., San Martín, H.: Garcia-De los Salmones, M.M: Explaining the adoption of social networks sites for sharing user-generated content: a revision of the UTAUT2. Comput. Hum. Behav. 71, 209-217 (2017)

36. Balouchi, M., Aziz, Y.A., Hasangholipour, T., Khanlari, A., Rahman, A.A., Raja-Yusof, R.N.: Explaining and predicting online tourists' behavioural intention in accepting consumer generated contents. J. Hosp. Tour. Technol. 8(2), 168-189 (2017)

37. Koch, S., Tritscher, F.: Social media in the airline industry: acceptance of social seating. J. Hosp. Tour. Technol. 8(2), 256-279 (2017)

38. Crompton, J.L.: An assessment of the image of mexico as a vacation destination and the influence of geographical location upon that image. J. Travel Res. 17(4), 18-23 (1979)

39. Martín-Santana, J.D., Beerli-Palacio, A., Nazzareno, P.A.: Antecedents and consequences of destination image gap. Ann. Tour. Res. 62, 13-25 (2017)

40. Lowry, P.B., Vance, A., Moody, G., Beckman, B., Read, A.: Explaining and predicting the impact of branding alliances and web site quality on initial consumer trust of e-commerce web sites. J. Manage. Inf. Syst. 24(4), 199-224 (2008)

41. Huang, S., Ku, H.: Brand image management for nonprofit organizations: exploring the relationships between websites, brand images and donations. J. Electron. Commer. Res. 17(1), 80-96 (2016)

42. Doosti, S., Jalilvand, M.R., Asadi, A., Pool, J.K., Mehrani, P.: Analyzing the influence of electronic word of mouth on visit intention: the mediating role of tourists' attitude and city image. Int. J. Tour. Cities 2(2), 137-148 (2016)

43. Prayogo, R.R., Ketaren, F.L.S., Hati, R.M.: Electronic word of mouth, destination image, and satisfaction toward visit intention: an emperical study in Malioboro Street, Yogyakarta. Adv. Soc. Sci. Educ. Humanit. Res. 81, 209-218 (2017)

44. Kim, S.E., Lee, K.Y., Shin, S.I., Yang, S.B.: Effects of tourism information quality in social media on destination image formation: the case of Sina Weibo. Inf. Manage. 54(6), 687-702 (2017)

45. Gomes, J., Montenegro, M.: Profile of female tourists visiting Porto and North of Portugal. Worldw. Hosp. Tour. Themes 8(6), 677-690 (2016)

46. Llodrà-Riera, I., Martínez-Ruiz, M.P., Jiménez-Zarco, A.I., Izquierdo-Yusta, A.: A multidimensional analysis of the information sources construct and its relevance for destination image formation. Tour. Manage. 48, 319-328 (2015) 
47. Xia, M., Zhang, Y., Zhang, C.: A TAM-based approach to explore the effect of online experience on destination image: a smartphone user's perspective. J. Destin. Mark. Manage., 1-12 (2017, In Press)

48. Blasco-Arcas, L., Hernandez-Ortega, B.I., Jimenez-Martinez, J.: Engagement platforms: the role of emotions to foster customer engagement and brand image in interactive media. J. Serv. Theory Pract. 26(5), 559-589 (2016)

49. Drengner, J., Gaus, H., Jahn, S.: Does flow influence the brand image in event marketing? J. Advert. Res. 48(1), 138-147 (2008)

50. Prayag, G., Hosany, S., Muskat, B., Chiappa, G.D.: Understanding the relationships between tourists' emotional experiences, perceived overall image, satisfaction, and intention to recommend. J. Travel Res. 56(1), 41-54 (2017)

51. Huang, S., Weiler, B., Assaker, G.: Effects of interpretive guiding outcomes on tourist satisfaction and behavioral intention. J. Travel Res. 54(3), 344-358 (2015)

52. del Bosque, I.R., San Martín, H.: Tourist satisfaction a cognitive-affective model. Ann. Tour. Res. 35(2), 551-573 (2008)

53. Lee, Y.K., Back, K.J., Kim, J.Y.: Family restaurant brand personality and its impact on customer's eMotion, satisfaction, and brand loyalty. J. Hosp. Tour. Res. 33(3), 305-328 (2009)

54. Song, J., Qu, H.: The mediating role of consumption emotions. Int. J. Hosp. Manage. 66, 6676 (2017)

55. Bigné-Alcañiz, E., Ruiz-Mafé, C., Aldás-Manzano, J., Sanz-Blas, S.: Influence of online shopping information dependency and innovativeness on internet shopping adoption. Online Inf. Rev. 32(5), 648-667 (2008)

56. Bigné, J.E., Andreu, L., Gnoth, J.: The theme park experience: an analysis of pleasure, arousal and satisfaction. Tour. Manage. 26(6), 833-844 (2005)

57. Chi, C.G.Q., Qu, H.: Examining the structural relationships of destination image, tourist satisfaction and destination loyalty: an integrated approach. Tour. Manage. 29(4), 624-636 (2008)

58. Prayag, G., Ryan, C.: Antecedents of Tourists' loyalty to Mauritius. J. Travel Res. 51(3), 342-356 (2012)

59. Beerli, A., Martín, J.D.: Tourists' characteristics and the perceived image of tourist destinations: a quantitative analysis - a case study of Lanzarote, Spain. Tour. Manage. 25(5), 623-636 (2004)

60. Han, H., Kiatkawsin, K., Jung, H., Kim, W.: The role of wellness spa tourism performance in building destination loyalty: the case of Thailand. J. Travel Tour. Mark., 1-16 (2017)

61. Forgas-Coll, S., Palau-Saumell, R., Sánchez-García, J., Callarisa-Fiol, L.J.: Urban destination loyalty drivers and cross-national moderator effects: The case of Barcelona. Tour. Manage. 33(6), 1309-1320 (2012)

62. Dix, S., Jamieson, K., Shimul, A.S.: SMS advertising the Hallyu way: drivers, acceptance and intention to receive. Asia Pac. J. Mark. Logist. 28(2), 366-380 (2016)

63. Ismail, A.R.: The influence of perceived social media marketing activities on brand loyalty. Asia Pac. J. Mark. Logist. 29(1), 129-144 (2017)

64. Baena, V.: Online and mobile marketing strategies as drivers of brand love in sports teams: findings from Real Madrid. Int. J. Sport. Mark. Spons. 17(3), 202-218 (2016). 2(5), 99-110 (2016) 